\title{
IMPURITIES IN SNOW: EFFECTS ON ALBEDO AND SNOWMELT
}

\author{
(Review)
}

\author{
by \\ Stephen G. Warren \\ (Geophysics Program and Department of Atmospheric Sciences, University of Washington, \\ Seattle, Washington 98195, U.S.A.)
}

\section{ABST RACT}

Very small (ppm) amounts of soil dust in snow can significantly reduce snow albedo and thereby affect the snow-surface energy budget. I ce cores from Greenland show enhanced dust concentrations in ice from the last glacial maximum, in amounts capable of causing measurable effects on snow albedo. This enhanced dust is probably due in part to the expanded desert areas at that time.

Volcanic ash layers visible in the Byrd station core reduced the snow albedo in West Antarctica when they were on the surface. The ash is unlikely to have had a long-term effect on albedo because of the episodic nature of volcanic eruptions.

Very large amounts of dust on snow can inhibit snow-melt by insulating the snow. A debris cover probably slowed the melting of parts of the North American ice sheet during its most recent decay phase. Snow in the Arctic Ocean is presently suffering large-scale contamination by carbon soot from anthropogenic sources. Preliminary estimates indicate that soot concentrations in Arctic snow are sufficient to reduce snow albedo measurably.

\section{THEORETICAL MODEL OF SNOW ALBEDO}

In order to explain the reasons for the large observed variability of snow albedo, Wiscombe and Warren (1980) designed a theoretical model of radiative transfer for the scattering and absorption of sunlight in snow. This model is useful for any wavelength in the solar spectrum, 0.2 to $5.0 \mu \mathrm{m}$. Snow albedo is very high (over $90 \%$ ) in the visible and near-ultraviolet, and is much lower in the nearinfrared, so most of the light absorbed by snow is near-infrared sunlight.

The normal reduction of snow albedo with age is attributed to the increase in grain size (or decrease in surface-to-volume ratio) that normally occurs with snow metamorphism. Snow albedo is reduced at all wavelengths as the grain size increases. In order to match the observed course of spectral albedo in the near-infrared, effective grain radi in the range $50 \mu \mathrm{m}$ (new snow) to about $1000 \mu \mathrm{m}$ (old melting snow) were required in the model.

\section{EFFECT OF DUST ON SNOW ALBEDO}

Trace amounts of light-absorbing impurities can significantly reduce snow albedo in the visible wave- lengths but have no effect on near-infrared albedo or thermal infrared emissivity.

Except in the Antarctic, most observations of visible snow albedo are lower than calculated for pure snow, and can be explained by assuming that the snow contained graphitic carbon "soot" in concentrations of 1 to $2 \times 10^{-7}$ by weight (Warren and Wiscombe 1980). This soot was probably mostly the result of local (camp) pollution, although part of it may be due to widespread pollution from northern hemisphere industrial sources, as discussed below.

The impurities which are most likely to have widespread effects on snow albedo are carbon soot, continental dust, and volcanic ash. Soot is about 50 times more effective than dust, and about 200 times more effective than ash, at reducing snow albedo.

The theoretical effect of soot on snow albedo was confirmed by Grenfell and others (1981). They measured the spectral albedo of natural snow in the Cascade Mountains, Washington, USA, and also collected samples of the snow for soot analysis. The soot content ( 2 to $6 \times 10^{-8}$ by weight) was roughiy in accord with the albedo reduction, as discussed by Warren (1982[b]).

\section{ICE-AGE-INDUCED DESERTIFICATION: A NEGATIVE FEER-} BACK ON ICE-SHEET GROWTH?

Ice cores from Antarctica and northern Greenland show enhanced concentrations of insoluble continental dust in ice from the last glacial maximum (Thompson 1977 , Lorius and others 1984). The enhancement is about a factor of 5 at Byrd station, 15 to 20 at Dome $C$, and 50 at Camp Century. The concentration of dust may have been 1 to $2 \mathrm{ppm}$ by weight at Camp Century. This is enough to reduce visible snow albedo (at $0.4 \mu \mathrm{m}$ wavelength) by $1 \%$ for new snow or $5 \%$ for old melting snow (Warren and Wiscombe 1980: fig.5(a),(c)). (This result was misquoted by Warren (1982[a]).) The effect on spectrally-integrated albedo would be about one-third of these values. We may expect larger quantities of dust at more southerly locations in Greenland and on the North American and Scandinavian ice sheets which were closer to the sources of dust.

The enhanced dust during the last glacial maximum may have been due to both expanded desert areas (Sarnthein 1978) and increased wind strength. The desertification may have been caused by the ice sheets themselves, by means of the associated cooling of ocean surface waters which suppressed the hydro- 
logical cycle, as suggested by the generalcirculation-modeling results of Manabe and Hahn (1977). This process leads to the well-known positive climatic feedback due to the albedo contrast between deserts and grasslands. However, the fallout of this desert dust in snow also leads to a potential negative feedback similar to one suggested by Kellogg (1975: fig.8). This speculation cannot be quantified until estimates of dust deposition rates on the Laurentide and Scandinavian ice sheets are available (Joussaume and others 1984).

\section{VOLCANIC ASH IN SNOW}

Volcanic ash layers visible in the Byrd station core (Gow and Williamson 1971) would have reduced the snow albedo in West Antarctica when they were on the surface (cf. Warren 1982[b]: fig.7). It is 1ikely that these ash layers came from Antarctic volcanoes which may have owed their enhanced activity to the greater ice burden on the continent (Kyle and others 1981). This suggests another negative feedback on icesheet growth which was proposed by Bloch (1964). However, because of the episodic nature of volcanic eruptions, the ash would soon be covered with new snow, so its effect would be short-lived. Because the snow does not melt over most of Antarctica, the ash remain hidden from sunlight once it is covered by new snow. The effect of volcanic ash on snow albedo is thus unlikely to have long-term climatic significance.

\section{VERY LARGE AMOUNTS OF DUST CAN INHIBIT ABLATION}

When snow melts, the impurities of ten tend to collect at the surface rather than washing away with the meltwater. During the decay phase of the northern hemisphere ice sheets, the southernmost portions may thus have been covered with debris. If the debris layer is sufficiently thick, the insulation of the ice becomes more important than the albedo reduction, and ablation can be reduced. The terminus of the Malaspina Glacier in Alaska is one modern example ( $\mathrm{H}$ Hall personal communication). The surface of such glaciers can even become vegetated. The critical thickness of debris, beyond which ablation is inhibited, has been measured as 5 to $10 \mathrm{~mm}$ for "dirt" (Ashwel1 and Hannell 1966), $20 \mathrm{~mm}$ for sand (Higuch i and Nagoshi 1977), and 20 to $30 \mathrm{~mm}$ for volcanic ash (Driedger 1981). The competing effects of debris are illustrated by contrasting cryoconite holes with dirt cones and glacier tables.

Layers of debris thicker than $20 \mathrm{~mm}$ may not have extended far from the ice front. For example, a $20 \mathrm{~mm}$ layer of dust could be formed by the ablation of $2000 \mathrm{~m}$ of ice if the ice contained a dust fraction of about $10^{-5}$, i.e. a factor of 10 higher than that found in ice from the last glacial maximum at Camp Century. It is thus doubtful that the delay of ice decay due to protection by dust would cause a noticeable lag in the oxygen isotope record in the ocean sediments. A quantitative assessment awaits estimates of dust deposition rates on the North American and Scandinavian ice sheets.

\section{EFFECT OF SOOT POLLUTION ON SNOW ALBEDO}

Carbon soot is produced by incomplete combustion. The major sources of soot at present are probably anthropogenic, both from the burning of coal and oil for industry, and from brush fires for agriculture. Natural forest fires can also contribute soot to the atmosphere. Soot is of current interest for its possible climatic effects as the absorptive component of the "Arctic haze" (Rosen and others 1981). This soot may be removed from the atmosphere in snowfall and thus be found in the snow on top of Arctic sea ice. Only one preliminary measurement of soot content in Arctic snow is now available (Rosen personal communication, cited by Warren 1982[b]). Rosen found weight fractions of 1 to $6 \times 10^{-8}$. A weight fraction of $5 \times 10^{-8}$ is enough to reduce visible snow albedo by $2.5 \%$ (new snow) to $7 \%$ (old melting snow) and spectrally-integrated albedo by $1 \%$ (new) to $2 \%$ (old), according to the model of Warren and Wiscombe. As discussed below, the soot may actually be more effective than they calculated. Better estimates of the climatic importance of carbon particles in Arctic snow await the results of the large-scale snow-sampling and soot-measurement program now underway by Antony Clarke at the University of Washington.

\section{IMPORTANCE OF THE LOCATION OF ABSORPTIVE IM- PURITIES IN SNOW}

Impurities can be more effective at reducing snow albedo if they are located inside the ice grains. Warren and Wiscombe (1980) modeled impure snow as an "external mixture", with separated ice and dust particles each surrounded by air. Ackerman and Toon (1981) have shown that the absorption of 1 ight is enhanced if the impurity is present as an "internal mixture". They did this for the case of soot particles in sulfuric acid droplets, which they modeled as concentric spheres, but the results also apply to soot in ice (cf. note added in proof to Warren 1982[b]). Chýlek and others (in press) have modeled soot in snow as an internal mixture, with small soot particles (mean radius about $0.1 \mu \mathrm{m}$ ) uniformly distributed through the much larger ice grains. They found that for a given effect on snow albedo, an external mixture requires about twice as much soot as an internal mixture requires.

These results will also apply qualitatively to continental dust: dust particles inside ice will be more absorptive than if they are surrounded by air. The enhanced absorption has not yet been calculated; it will probably not be as dramatic as for soot because of the larger size (radius $\sim 1 \mu \mathrm{m}$ ) of the dust particles.

\section{ACKNOWLEDGEMENT}

My research on optical properties of snow and ice is supported by National Science Foundation grant ATM-82-15337. This is Contribution No.680 from the Department of Atmospheric Sciences, University of Washington.

\section{REFERENCES}

Ackerman T P, Toon O B 1981 Absorption of visible radiation in atmosphere containing mixtures of absorbing and nonabsorbing particles. Applied optics 20(20): 3661-3668

Ashwell I Y, Hannell F G 1966 Experiments on a snowpatch in the mountains of Sweden. Joumal of Glaciology 6(43): 135-144

Bloch M R 1964 Dust-induced albedo changes of polar ice sheets and glacierization. Joumal of Glaciology 5(38): 241-244

Chýlek P, Ramaswamy V, Srivastava V In press Albedo of soot-contaminated snow. Joumal of Geophysical Research

Driedger C L 1981 Effect of ash thickness on snow ablation. The 1980 eruptions of Mount St. Helens, Washington. US Geological Survey. Professional Paper 1250: 757-760

Gow A J, Williamson T 1971 Volcanic ash in the Antarctic ice sheet and its possible climatic implications. Earth and Planetary Science Letters 13(1): 210-218

Grenfell T C, Perovich D K, Ogren J A 1981 Spectral albedos of an alpine snowpack. Cold Regions Science and Technology 4(2): 121-127

Higuchi K, Nagoshi A 1977 Effect of particulate matter in surface snow layers on the albedo of perennial snow patches. Intermational Association of Hydrological Sciences Publication 118 (General Assembly of Grenoble 1975 - Isotopes and Impurities in snow and Ice): $95-97$ 
Joussaume S, Rasool I, Sadourny R, Petit J-R 1984 Simulation of desert dust cycles in an atmospheric general circulation model (Abstract). Annals of Glaciology 5: 204-207

Kellogg W W 1975 Climatic feedback mechanisms involving the polar regions. In Weller G, Bowling $S A$ (eds) Climate of the Arctic. Fairbanks, AK, University of Alaska. Geophysical Institute: 111-116

Kyle $P$, Jezek $P$ A, Mosley-Thompson E, Thompson $L G$ 1981 Tephra layers in the Byrd station ice core and the Dome C ice core, Antarctica and their climatic importance. Joumal of Volcanology and Geothermal Research 11(1): 29-39

Lorius C, Raynaud D, Petit J-R, Jouzel J, Merl ivat L 1984 Late-glacial maximum-Holocene atmospheric and ice-thickness changes from Antarctic ice-core studies. Annals of Glaciology 5: 88-94

Manabe S, Hahn D G 1977 Simulation of the tropical climate of an ice age. Joumal of Geophysical Research 82(27): 3889-3911

Rosen H, Novakov T, Bodhaine B A 1981 Soot in the Arctic. Atmospheric Environment 15(8): 1371-1374 Sarnthein M 1978 Sand deserts during glacial maximum and climatic optimum. Nature 272(5648): 43-46

Thompson L G 1977 Variations in microparticle concentration, size distribution and elemental composition found in Camp Century, Greenland, and Byrd station, Antarctica, deep ice cores. Intermational Association of Hydrological Sciences Publication 118 (General Assembly of Grenoble 1975 - Isotopes and Impurities in Snow and Ice): 351-364

Warren S G 1982[a] Ice and climate modeling: an editorial essay. Climatic Change 4(4): 329-340

Warren S G 1982[b] Optical properties of snow. Reviews of Geophysics and Space Physics 20(1): 67-89

Warren S G, Wiscombe W J 1980 A model for the spectral albedo of snow. II. Snow containing atmospheric aerosols. Joumal of the Atmosphemic Sciences 37(12): 2734-2745

Wiscombe W J, Warren S G 1980 A model for the spectral aibedo of snow. I. Pure snow. Joumal of the Atmospheric Sciences 37(12): 2712-2733 